\title{
Harttia absaberi, a new species of loricariid catfish (Siluriformes: Loricariidae: Loricariinae) from the upper rio Paraná basin, Brazil
}

\author{
Osvaldo Takeshi Oyakawa ${ }^{1}$, Ilana Fichberg ${ }^{1}$ and Francisco Langeani ${ }^{2}$
}

\begin{abstract}
A new species of Harttia, tribe Harttiini, is described from tributaries of upper portions of rio Paraná drainage. The new species, the smallest known species of the genus, attaining up to $74.0 \mathrm{~mm}$ of standard length, can be distinguished from its congeners by the combination of the following characters: abdomen completely covered by plates, a single preanal plate, plates of the gular area in broad contact with the canal plate. Harttia absaberi is the second species of the genus known from the upper portion of rio Paraná drainage.

Uma espécie nova de Harttia, tribo Harttiini, é descrita dos tributários da porção superior da drenagem do rio Paraná. A espécie nova, a menor espécie conhecida do gênero, alcançando até $74,0 \mathrm{~mm}$ de comprimento padrão, pode ser diferenciada de suas congêneres pela combinação dos seguintes caracteres: abdômen completamente coberto por placas ósseas, uma única placa preanal, placas da região gular em contato amplo com a placa portadora de canal. Harttia absaberi é a segunda espécie do gênero conhecida da porção superior da drenagem do rio Paraná.
\end{abstract}

Key words: Harttiini, Loricarioidea, Neotropical fishes, Ostariophysi, Taxonomy.

\section{Introduction}

Loricariinae comprises a monophyletic group within the Loricariidae (Schaefer, 1987, Rapp Py-Daniel, 1997, Montoya-Burgos et al., 1998, Armbruster, 2004, Reis et al., 2006, Covain \& Fisch-Muller, 2007), with 229 valid nominal species distributed in 32 to 34 genera according to Covain \& Fisch-Muller (2007), Ferraris (2007), Rodriguez et al. (2011) and Covain et al. (2012), widely distributed throughout Central and South America drainages from Costa Rica to northern Argentina, and with the greatest diversity in the Amazon region. Members of the subfamily are easily recognized by an elongate and depressed caudal peduncle and by the absence of an adipose fin. Harttiinae was created by Boeseman (1971) as a subfamily, to include the genera Farlowella Eigenmann \& Eigenmann, Harttia Steindachner, Harttiella Boeseman, Parasturisoma Miranda Ribeiro, and Sturisoma Swainson. Later, Isbrücker (1979) included the genera Sturisoma, Harttia, Lamontichthys Miranda Ribeiro, Harttiella, Pterosturisoma Isbrücker \& Nijssen, Cteniloricaria Isbrücker \& Nijssen, Sturisomatichthys Isbrücker
\& Nijssen, and Metaloricaria Isbrücker in his concept of Harttiini. Harttiini sensu Rapp Py-Daniel (1997) is a monophyletic assemblage diagnosed by several synapomorphies, such as: preopercle ventral process present, second basibranchial vestigial, basipterygia cartilage plug short, lips with plates, more than 50 jaw teeth, palatine anterior process present, upper pharyngeal plate with bony shelf. This author included within the Harttiini the genera Aposturisoma Isbrücker, Britski, Nijssen \& Ortega, Farlowella, Harttia, Lamontichthys and Sturisomatichthys with Cteniloricaria as a junior synonym of Harttia. Covain \& Fisch-Muller (2007) expanded the tribe to include Harttiella, Metaloricaria, Pterosturisoma, and Sturisoma, and more recently Covain et al. (2012) considered Harttiini as composed by Cteniloricaria (revalidated), Harttia, and Harttiella.

The genus Harttia is readily recognized by a set of morphologic features as absence of keels on lateral plates, snout round, large plates surrounding the anal opening (Boeseman, 1971) and abrupt narrowing of caudal peduncle. Additionally Harttia can be distinguished from its congeners by the following synapomorphies: basipterygia internal

${ }^{1}$ Museu de Zoologia da Universidade de São Paulo, Caixa Postal 42494, 04218-970 São Paulo, SP, Brazil. oyakawa.usp.br (OTO), ilanafic@gmail.com (IF)

${ }^{2}$ UNESP, Universidade Estadual Paulista, Laboratório de Ictiologia, Rua Cristóvão Colombo, 2265, 15054-000 São José do Rio Preto, SP, Brazil. kikolangeani@gmail.com 
anterior processes oriented mesially, not contacting each other, point of bifurcation of the infraorbital and supraorbital canals at the border between sphenotic and pterotic-supracleithrum, first ceratobranchial with huge flange, parapophysis of fourth vertebra not contacting transcapular ligament, parietal branch terminal opening on the supraocciptal, preopercle canal straight with three exits (Rapp Py-Daniel, 1997).

With 22 nominal valid species, Harttia exhibits the third higher intrageneric diversity within the Loricariinae. Only Rineloricaria Bleeker with 65 species (Vera-Alcaraz et al., 2012) and Farlowella with 25 species (Ferraris, 2007) are more diverse than Harttia. The genus has a broad distribution in South America, ranging from the rio Ribeira de Iguape basin (Harttia kronei Miranda Ribeiro), in São Paulo State, Brazil, to Caura River (Harttia merevari Provenzano, MachadoAllison, Chernoff, Willink \& Petry), in the rio Orinoco drainage. Among those 22 species, the majority described in the last two decades, ten were described for the Eastern and Southeastern Brazil, seven for the Amazonian region, and five for the Guianas and Venezuela region.

Despite of many species that have been described in the last 20 years, there are at least 10 other putative new species from North and Southeastern Brazil besides the new species described herein (pers. obs.). Harttia absaberi $\mathrm{n}$. sp. is the second species of Harttia described to the upper rio Paraná basin, with Harttia gracilis Oyakawa, being the first one. At this time in the upper Paraná basin, the subfamily is represented only by 13 species belonging to the following five genera: Farlowella, Loricaria, Loricariichthys Bleeker, Rineloricaria, and Harttia (Ferraris, 2007). Despite being one of the most studied freshwater systems in Brazil, the new species described herein reinforces the suggestions addressed by Langeani et al. (2007) that the diversity of this drainage is indeed underestimated.

\section{Material and Methods}

Point-to-point measurements were made with caliper on the left side of specimens whenever possible, and were recorded to the nearest $0.1 \mathrm{~mm}$. Measurements and counts follow Langeani et al. (2001), counts of trunk lateral dermal plates follow Schaefer (1997), osteological terminology follows Schaefer (1987) and Paixão \& Toledo-Piza (2009). In the description the numbers between square brackets refer to the modes. Measurements are expressed as percents of standard length (SL) unless those referring to subunits of head, which are expressed as percents of head length (HL). Some specimens (indicated by c\&s) were cleared and double stained for bone and cartilage according the method of Taylor \& Van Dyke (1985). Institutional abbreviations are: ANSP, Academy of Natural Sciences of Drexel University, Philadelphia, CAS; California Academy of Sciences, San Francisco; DZSJRP, Departamento de Zoologia e Botânica, Universidade
Estadual Paulista “Júlio de Mesquita Filho", São José do Rio Preto; INPA, Instituto Nacional de Pesquisa da Amazônia, Manaus; MNRJ, Museu Nacional, Rio de Janeiro; MZUEL, Museu de Zoologia da Universidade Estadual de Londrina, Londrina; MZUSP, Museu de Zoologia da Universidade de São Paulo, São Paulo, and RMNH.PISC, Netherlands Centre for Biodiversity Naturalis (formerly Rijksmuseum van Natuurlijke Historie), Leiden.

\section{Results}

\section{Harttia absaberi, new species Figs. 1-6}

Holotype. MZUSP 85805, 60.4 mm SL, Brazil, Mato Grosso do Sul State, Três Lagoas, ribeirão São Mateus, tributary of the rio Sucuriú, rio Paraná basin,23 Sep 2003, O. T. Oyakawa, J. C. Nolasco, J. L. Birindelli \& C. N. Kikuchi.

Paratypes. All from Brazil. Rio Paraná basin. Mato Grosso do Sul State. MZUSP 22848, 2, 58.4-63.9 mm SL, Três Lagoas, córrego do Bebedouro, tributary of the rio Sucuriú, 22²1'5.2"S 51 ${ }^{\circ} 53$ '52.9”W, 11-23 Nov 1964, Excursão Departamento de Zoologia. São Paulo State. DZSJRP 2741, 1, 67.6 mm SL, Ipeúna, rio Passa Cinco, Fazenda Palmeira, no date, Equipe Laboratório de Citogenética UFSCar. MZUEL 5007, 2, 66.2-67.4 mm SL, same locality as DZSJRP 2741. MZUSP 58674, 3, 59.2-74.1 mm SL, Ipeúna, rio Passa Cinco, no date, Equipe Laboratório de Citogenética UFSCar. MZUSP 85806, 36, (2 c\&s), 44.1-63.9 mm SL, same data as the holotype. MZUSP 87921, 2, 58.1-60.3 mm SL, Itirapina, rio Passa Cinco, 22²2'19”'S 4746'55”W, 19 Jan 2002, E. N. Fragoso.

Diagnosis. Harttia absaberi is distinguished from its congeners, except Harttia rhombocephala Miranda Ribeiro, H. longipinna Langeani, Oyakawa \& Montoya-Burgos, H. punctata Rapp PyDaniel \& Oliveira, H. duriventris Rapp Py-Daniel \& Oliveira, H. dissidens Rapp Py-Daniel \& Oliveira, H. trombetensis Rapp Py-Daniel \& Oliveira, H. fowleri (Pellegrin), and $H$. surinamensis Boeseman, by having the abdomen completely covered by plates. From the above-mentioned species it can be distinguished by having only one preanal plate versus two or three, usually two, in adults specimens. In addition, H. absaberi can be distinguished from the above-mentioned species by possessing the plates of the gular area in broad contact with the canal plate and partially contacting the border of the lower lip. In the gular area of above-mentioned species, a small area remains unplated or naked, and the plates never touch the canal plate. Moreover, H. absaberi can be distinguished from its congeners by having a thin series of small plates on the upper lip versus upper lip completely naked in all other species, except Harttia duriventris, which possess around five small plates on the upper lip. 


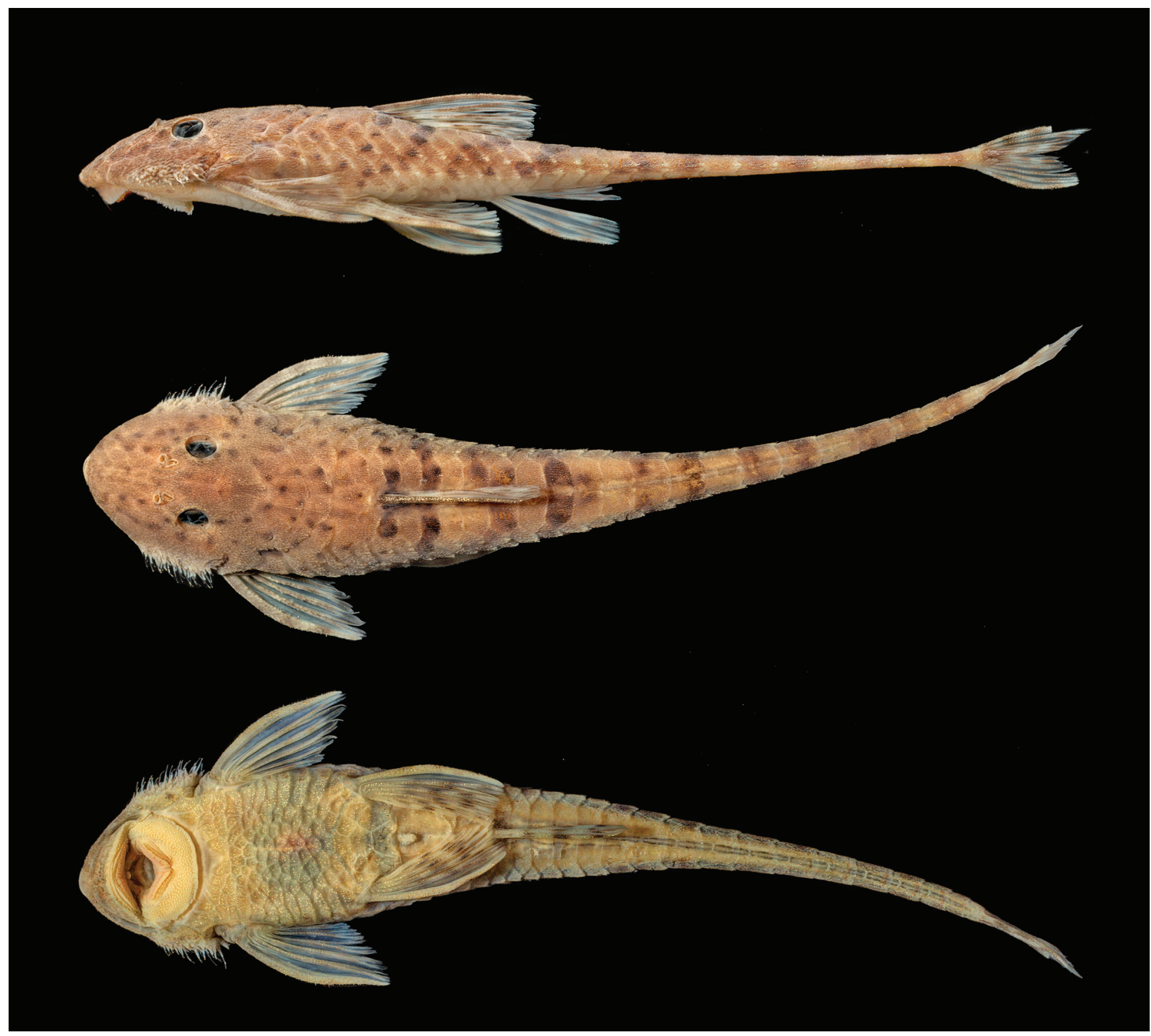

Fig. 1. Harttia absaberi, new species, MZUSP 85805, 60.4 mm SL, holotype, Brazil, Mato Grosso do Sul State, Três Lagoas, ribeirão São Mateus, tributary of the rio Sucuriú, rio Paraná basin. From top to bottom: lateral, dorsal and ventral views.

Description. Measurements and counts of plates in Table 1. Body dorsoventrally depressed and elongated, widest at cleithrum. Dorsal profile moderately convex from tip of snout to end of parieto-supraoccipital, straight to dorsal-fin origin and gently descending to e nd of caudal peduncle. Ventral profile straight from tip of snout to caudal fin.

Head moderately rounded. Snout tip pointed in dorsal view. Posterior margin of parieto-supraoccipital bordered by four plates. Eye roundish and small. Dorsal flap of iris present. Interorbital region straight. Lateral margin of head in nuptial males covered by numerous and thick odontodes, usually slightly turned posteriorly. Tip of snout with small, oval and naked area extending backward and joined with naked region of anterior area of upper lip. Anterior area of upper lip with thin line of small plates with odontodes. Lips rounded with papillae on edges. Inner surfaces of lips covered by papillae, more numerous and smaller in lower lip. Posterior border of lower lip almost reaching anterior margin of scapular bridge. Premaxilla with 31-58 [33] bicuspid teeth, both cusps with same size, dentary with 29-36 [32] teeth, inner cusp slightly longer than outer. Maxillary barbel reaching up to $1 /{ }_{4}$ of lower lip length, and sometimes joined to lip by small flap of tissue. Infraorbital series with five plates, last one contacting inferior branch of sphenotic. Inferior region of orbit delimited by infraorbitals $3-5$. Canal plate roughly rectangular, completely covered by odontodes and bearing section of laterosensorial system canal (Fig. 2). Bifurcation of infraorbital and supraorbital canals at middle of sphenotic bone. Parietal branch terminal opening on supraoccipital. 
Abdominal region between gular area to anus covered by roughly trapezoidal to quadrangular plates, without forming any regular pattern. Plates near gular area extensively contacting canal plate. Plates near anal plate larger than those in gular area. Abdominal scutation varying ontogenetically: specimens up to $30.0 \mathrm{~mm}$ SL with scattered small patches of odontodes, more concentrated near urogenital pore, and two small preanal plates, specimens between 31.0 to $33.0 \mathrm{~mm} \mathrm{SL}$ with same number of preanal plates, with numerous small patches of odontodes, specimens above $35.0 \mathrm{~mm}$ SL with abdomen covered by plates only posteriorly to scapular bridge and one preanal plate, specimens larger than $43.0 \mathrm{~mm}$ SL with abdomen completely covered by plates and one large preanal plate. Plates of gular area contacting canal plate.

Two series of plates between parieto-supraoccipital and nuchal plate (Fig. 3). First plate of dorsal series located laterally to nuchal plate, last plate contacting first dorsal procurrent ray of caudal fin. Mid-dorsal series with 11 plates, first located laterally to first plate of dorsal series. Median series with 27-29 [28], not keeled, plates bearing lateral-line canal. Mid-ventral series with 15 plates, first contacting posterior portion of cleithrum, last laterally to fifteenth plate bearing lateral-line canal. First plate of ventral series just above ventral-fin insertion, last one contacting first ventral procurrent ray of caudal fin. Anus surrounded anteriorly by one trapezoidal plate. Lateral abdominal plates between pectoral and pelvic-fin base 6-10 [8]. Three pairs of postanal plates. Post-anal plate 1 , very large and roughly triangular, latero posteriorly to anus, contacting each other at midline via broad suture (Fig. 4). Pairs of post-anal plates 2 and 3 separated by first pterygiophore of anal fin.

Dorsal fin I, 7, its origin on vertical above pelvic-fin origin. Spinelet half-moon shaped, approximately with same width of base of second dorsal-fin spine. Dorsal-fin spine articulates with pterygiophore via specialized chain-link structure (Fig. 5). Tip of last rays of dorsal fin surpassing point of insertion of last ray of anal fin when adpressed. Pectoral fin I,6. Tip of pectoral-fin spine and first two branched rays surpassing insertion of pelvic-fin spine. Odontodes covering partially dorsal region of cleithrum, spine and first three branched rays of pectoral fin. Pelvic fin I,5. Tip of pelvic-fin spine and first three branched rays surpassing insertion of anal-fin spine. Caudal fin I,12,I, with three to five supracaudal plates on its base, median plate bearing lateral line canal. Two procurrent rays on base of upper and lower caudal-fin rays. Dorsalmost

Table 1. Morphometrics and counts of plates of type specimens of Harttia absaberi $. \mathrm{N}=$ number of specimens, Min $=$ minimum value, Max = maximum value.

\begin{tabular}{|c|c|c|c|c|c|}
\hline & Holotype & $\mathbf{N}$ & Min & Max & Mean \\
\hline Standard Length & 60.4 & 23 & 44.1 & 74.1 & - \\
\hline \multicolumn{6}{|l|}{ Percents of Standard Length } \\
\hline Body depth & 11.4 & 23 & 9.4 & 14.1 & 11.5 \\
\hline Body width at dorsal-fin origin & 15.9 & 23 & 13.2 & 19.5 & 15.7 \\
\hline Post-dorsal length & 59.1 & 23 & 54.1 & 60.8 & 57.9 \\
\hline Post-anal length & 52.3 & 23 & 46.1 & 54.2 & 51.0 \\
\hline Dorsal-fin length & 19.5 & 23 & 16.4 & 20.5 & 19.0 \\
\hline Pectoral-fin length & 19.0 & 23 & 16.9 & 22.2 & 19.2 \\
\hline \multicolumn{6}{|l|}{ Percents of Head Length } \\
\hline Head width & 86.1 & 23 & 79.3 & 90.1 & 84.0 \\
\hline Orbital diameter & 16.6 & 23 & 14.7 & 19.7 & 17.5 \\
\hline Interorbital distance & 26.9 & 23 & 24.9 & 31.0 & 27.4 \\
\hline Snout length & 59.1 & 23 & 56.1 & 62.7 & 58.0 \\
\hline \multicolumn{6}{|l|}{ Counts } \\
\hline Lateral line plates & 28 & 22 & 27 & 29 & 28 \\
\hline Thoracic plates & 10 & 22 & 6 & 10 & 8 \\
\hline Dorsal-Caudal plates & 16 & 22 & 16 & 18 & 17 \\
\hline
\end{tabular}


caudal-fin ray with short and thick filament. Anal fin I,5. Tips of first and last basal radials of anal fin lying below hemal spines of vertebrae 14-18, respectively. Hemal spines of vertebrae 14-18 bifid, hemal spines of vertebrae 14, 16, and 18 very large. First anal-fin pterygiophore roughly square shaped and not covered by skin.

Color in alcohol. Dorsal region of body dark yellow to light brown, with five transverse dark brown bands, first at origin of dorsal fin, second starting at end of last rays of dorsal fin, followed by third and fourth in middle of caudal peduncle, and fifth at origin of caudal-fin rays. In some specimens, including holotype, anterior and posterior margins of bands more intensely pigmented. Ventral region light brown. All fin rays with dark brown spots, interradial membranes hyaline. Base of anal-fin spine with dark brown spot. Dorsal surface of upper lip ligth brown, snout tip greywish.

Geographical distribution. Harttia absaberi is currently known from three localities in the upper rio Paraná drainage: rio Passa Cinco, a tributary of the rio Piracicaba, rio Tietê drainage, São Paulo State, and two small creeks tributaries of the rio Sucuriú, at Três Lagoas, Mato Grosso do Sul State (Fig. 6).

Ecological notes. The ribeirão São Mateus, where the holotype was collected, is a small creek with sand bottom, clear water and about 1.0-2.0 m width and $0.5 \mathrm{~m}$ deep, which drains to the rio Sucuriú. The rio Passa Cinco is a relatively large river about $5.0-10.0 \mathrm{~m}$ wide and $1.0-2.0 \mathrm{~m}$ deep, with fast flowing clear water with sand in the bottom and stretches with rocks.

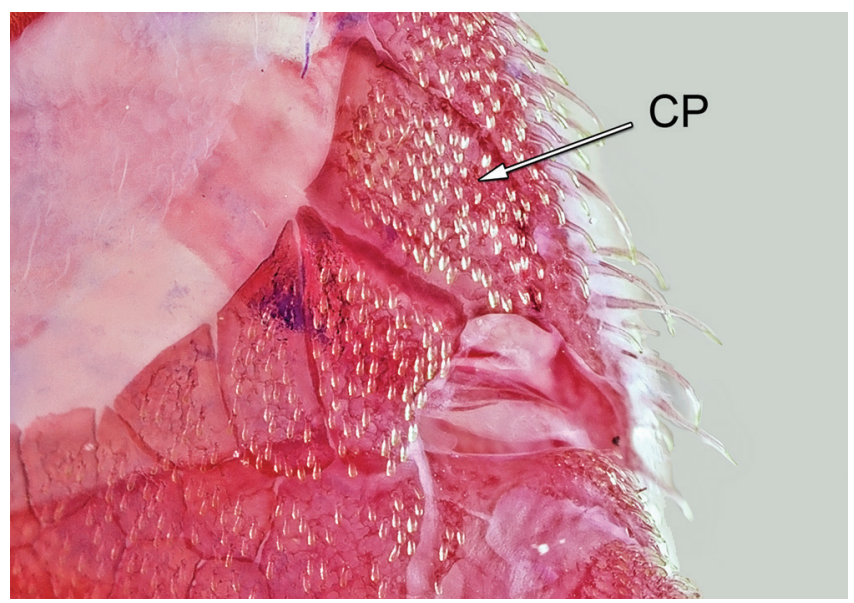

Fig. 2. Detail of the head, left side, of Harttia absaberi, showing the canal plate in ventral view. Canal plate (CP). MZUSP 85806, paratype, $63.9 \mathrm{~mm} \mathrm{SL}$, c\&s.

Etymology. The specific name, absaberi, is a patronym that honors Aziz Nacib Ab'Saber, whose contributions represent a landmark in the knowledge of geography, ecology and geomorphology of the Brazilian territory.

\section{Discussion}

Among all nominal valid species of Eastern and Southeastern Brazil, only Harttia rhombocephala, $H$. longipinna, and H. absaberi share the presence of numerous small osseous plates completely or almost completely covering the abdominal region. In the Guianas region (including

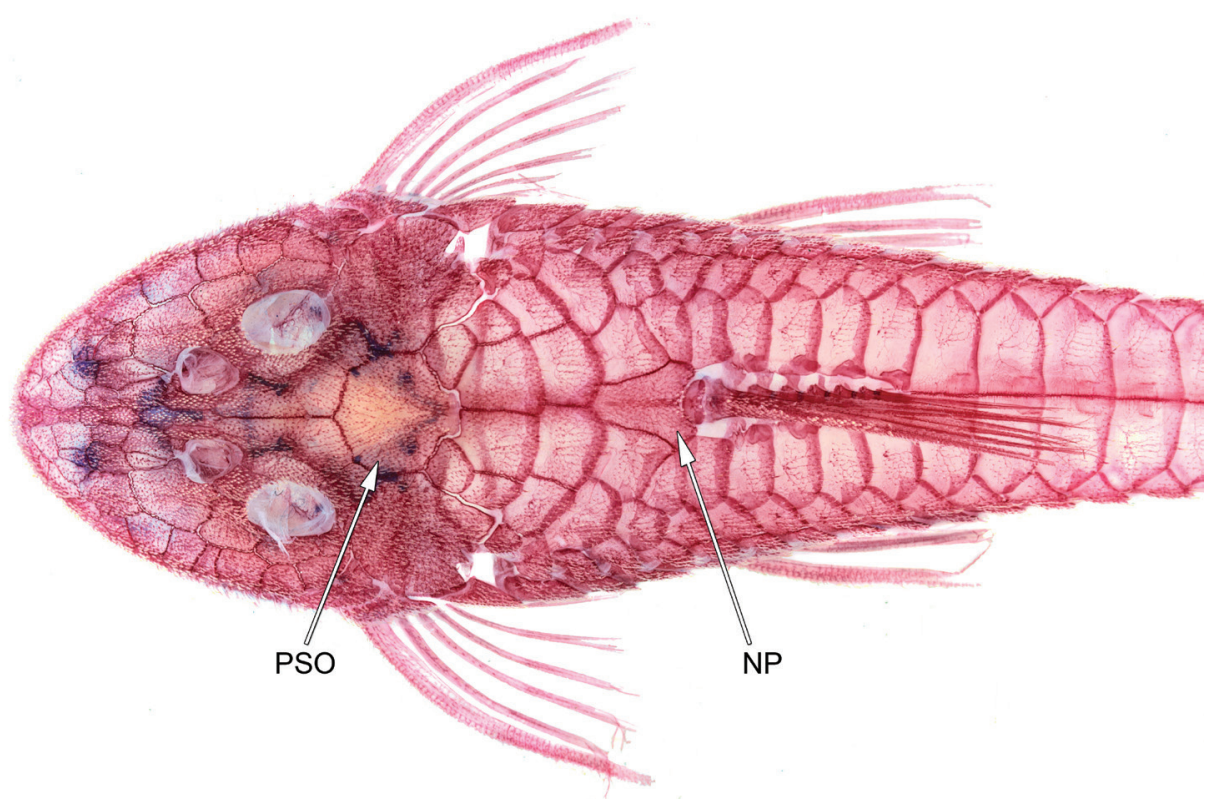

Fig. 3. Dorsal view of Harttia absaberi, showing the pattern of scutes between the parieto-supraoccipital (PSO) and the nuchal plate (NP). MZUSP 85806, paratype, $63.9 \mathrm{~mm} \mathrm{SL}$, c\&s. 


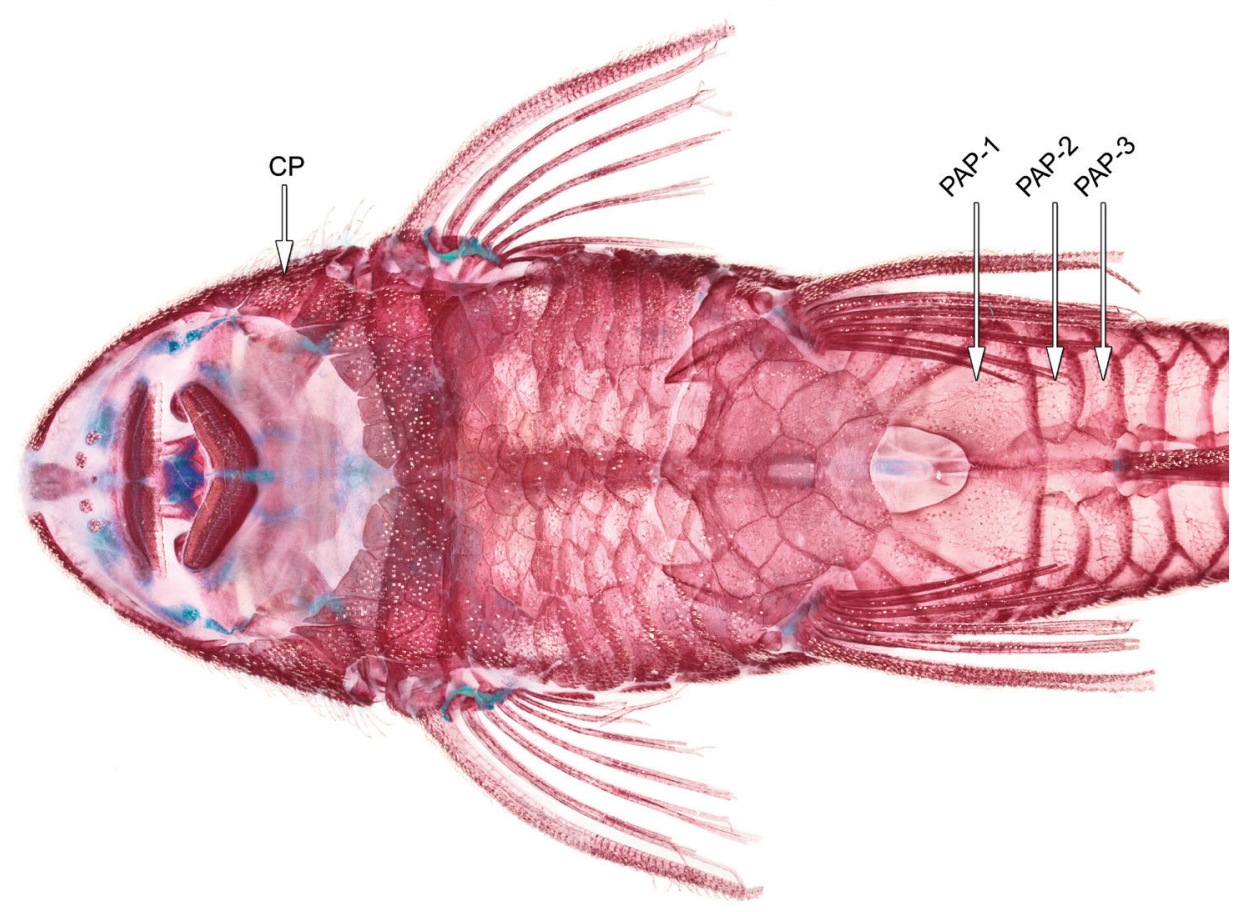

Fig. 4. Ventral view of Harttia absaberi. Canal plate (CP), preanal plates (PAP 1, PAP 2, PAP 3). MZUSP 85806, paratype, $63.9 \mathrm{~mm} \mathrm{SL}, \mathrm{c} \& \mathrm{~s}$.

Venezuela), only $H$. fowleri and $H$. surinamensis have the abdomen completely covered by osseous plate, whereas in $H$. guianensis Rapp Py-Daniel \& Oliveira and H. merevari, the abdomen is naked. Concerning the Amazonian species, only Harttia dissidens, $H$. duriventris and $H$. punctata have the abdomen covered by osseous plate. Even though all the abovementioned species have the abdomen plated, only Harttia absaberi has the abdominal plates almost reaching the border of the lower lip and in a broad contact with the canal plate. Within the other genera of Harttiini (sensu Covain et al., 2012), Ctenilocaria has the abdomen completely covered by plates, and species of Harttiella have the abdomen completely naked.

Adult specimens of Harttia absaberi, up to $35.0 \mathrm{~mm}$ $\mathrm{SL}$, have only one large preanal plate. In all others species of Eastern and Southeastern Brazil the anal plate varies between the complete absence (H. carvalhoi Miranda Ribeiro, H. kronei, H. leiopleura Oyakawa, H. novalimensis Oyakawa and $H$. garavelloi Oyakawa) and two plates $(H$. loricariformis Steindachner, $H$. rhombocephala Miranda Ribeiro, H. gracilis Oyakawa and H. longipinna), with the exception of $H$. torrenticola Oyakawa which has four, or sometimes more than four roundish anal plates. All species from the Amazon basin and Guianas region have two, two to three, or three or four preanal plates, usually quadrangular or pentagonal shaped. Among the other genera of Harttiini, only Harttiella has no plate.
Harttia absaberi has a thin series of bony plates on upper lip and excepting $H$. duriventris, which has very few and small plates on upper lip, all remaining species of Harttia have the upper lip completely naked. Concerning other Harttiini genera, Cteniloricaria and Harttiella have the upper lip naked.

Harttia absaberi shares with other 10 species the presence of the spinelet, whereas the spinelet is absent in the remaining twelve species. Concerning other Hartiini the spinelet is present in Cteniloricaria and absent in Harttiella.

Another structure related to the dorsal fin that exhibits great variation within the Harttiini as a whole and particularly among the species of Harttia is the type of articulation between the proximal portion of the dorsal-fin spine and the second dorsalfin pterygiophore. In the majority of the species of Harttia, in Cteniloricaria and Harttiella, the dorsal-fin spine articulates with the second dorsal-fin pterygiophore through a condyle. Only Harttia absaberi, H. fowleri, H. duriventris and H. punctata share the articulation of dorsal-fin spine with the second pterygiophore as a specialized chain-link structure (Schaefer, 1987).

Comparative material. Aposturisoma myriodon: Peru, Portillo, Aguaytia River, MZUSP 15328, $159.0 \mathrm{~mm}$ SL, holotype of Aposturisoma myriodon Isbrücker, Britski, Nijssen \& Ortega, 1983. Cteniloricaria platystoma: French Guiana, fleuve Maroni, RMNH. PISC 120.887, 1, 152.4 mm SL. Suriname, Marowijne drainage, ANSP 187330, 1, 147.3 mm SL, Lawa Rivier, MZUSP 100139, 1, 
$60.5 \mathrm{~mm}$ SL, Marowijne Rivier. Venezuela, Orinoco basin, 50.5 km SE of Ciudad Bolivar, MZUSP 109251, 3, 83.0-95.5 mm SL. Farlowella amazona: Brazil, Pará, Monte Dourado, rio Jari, MZUSP 103309, 1, 200.0 mm SL. Harttia carvalhoi: Brazil, Rio de Janeiro State, Resende, rio Pomba, tributary to rio Pirapitinga, MZUSP 44505, 13, 25.8-71.4 mm SL. Harttia depressa: Brazil, Amazonas State, rio Uatumã drainage, rio Pitinga, INPA 3120, 2, 92.0-95.0 mm SL. Harttia dissidens: Brazil, Pará State, Pimental, rio Tapajós, INPA 7046, 10, 95.3-133.2 mm SL. Harttia duriventris: Brazil, Pará State, rio Tocantins, igarapé Canoal, INPA 2969, 3, 71.2-86.2 mm SL. Harttia fowleri: Brazil, Amapá State, rio Araguari, INPA 7845, 1, 88.9 mm SL c\&s. Harttia garavelloi: Brazil, Minas Gerais State, rio Fanado, bridge at Minas Novas, MZUSP 43266, $85.7 \mathrm{~mm}$ SL, holotype of Harttia garavelloi Oyakawa, 1993. Harttia gracilis: Brazil, Minas Gerais State, Fortaleza de Minas, creek tributary to rio São João, MZUSP 43267, 101.4 mm SL, holotype of Harttia gracilis Oyakawa, 1993. Harttia guianensis: French Guiana, rio Sinnamary, INPA 14985, 2, 63.6-97.2 mm SL. Harttia kronei: Brazil, São Paulo State, Iporanga, rio Betari, MNRJ 713A, 1, 96.3 mm SL, Lectotype of Harttia kronei Miranda Ribeiro, 1908, designated by Miranda Ribeiro (1953: 400). Brazil, São Paulo State, Miracatu, creek tributary to rio Bananal, MZUSP 36553, 17, 51.0-82.3 mm SL. Harttia leiopleura: Brazil, Minas Gerais State, rio das Velhas basin, small stream tributary to córrego Mutuca, MZUSP 43264, $57.6 \mathrm{~mm} \mathrm{SL}$, holotype of Harttia leiopleura, Oyakawa, 1993. Harttia longipinna: Brazil, Minas Gerais State, rio Pará, bridge on the BR-262 road, MZUSP 54579, $107.2 \mathrm{~mm}$ SL, holotype of Harttia longipinna Langeani, Oyakawa \& MontoyaBurgos, 2001. Harttia loricariformis: Brazil, Minas Gerais State, Santa Bárbara do Tugúrio, rio Tinguá, tributary of rio Pomba, MZUSP 49263, 23, 32.8-156.4 mm SL. Harttia merevari: Venezuela, Bolivar State, río Caura , MZUSP 103072, 1, 78.9 mm SL, paratype of Harttia merevari Provenzano, Machado-Allison, Chernoff, Willink \& Petry, 2005. Harttia novalimensis: Brazil, Minas Gerais State, small stream tributary of córrego Mutuca, MZUSP 43262, $58.0 \mathrm{~mm}$ SL, holotype of Harttia novalimensis Oyakawa, 1993. Harttia punctata: Brazil, Goiás State, rio Paranã, MZUSP 58676, 14, 87.6-138.4 mm SL. Harttia rhombocephala: Brazil, Rio de Janeiro State, rio Farias, small creek tributary of Baía da Guanabara, MNRJ 712, 102.4 mm SL, holotype of Harttia rhombocephala Miranda Ribeiro, 1939. Harttia surinamensis: Suriname, Brokopondo, Suriname River, RMNH.PISC 106521, 1, 138.1 mm SL, Suriname, Marowijne drainage, Lawa River, ANSP 187328, 4, 69.0-129.7 mm SL. Harttia torrenticola: Brazil, Minas Gerais State, Moeda, Água Limpa, creek tributary of rio Paraopeba, at Serra da Moeda, MZUSP 43283, 77.0 mm SL, holotype of Harttia torrenticola Oyakawa, 1993. Harttia trombetensis: Brazil, Pará State, Oriximiná, rio Trombetas, INPA 3011, 10, 73.8-131.6 mm SL. Harttia uatumensis: Brazil, Amazonas State, Presidente Figueiredo, rio Uatumã, INPA 15659, 2, 73.7-74.4 mm SL. Harttiella crassicauda: Suriname Maroni River, Paramaka creek, tributary of Ijskreek, MZUSP 104502, 9 (2 c\&s), 27.6$30.8 \mathrm{~mm}$ SL. Lamontichthys filamentosus: Peru, Iquitos, Rio Amazonas, MZUSP 85803, 2, 150.5-159.0 mm SL. Metaloricaria paucidens: Suriname, Marowijne drainage, Lawa River, ANSP 187325, 2, 146.0-

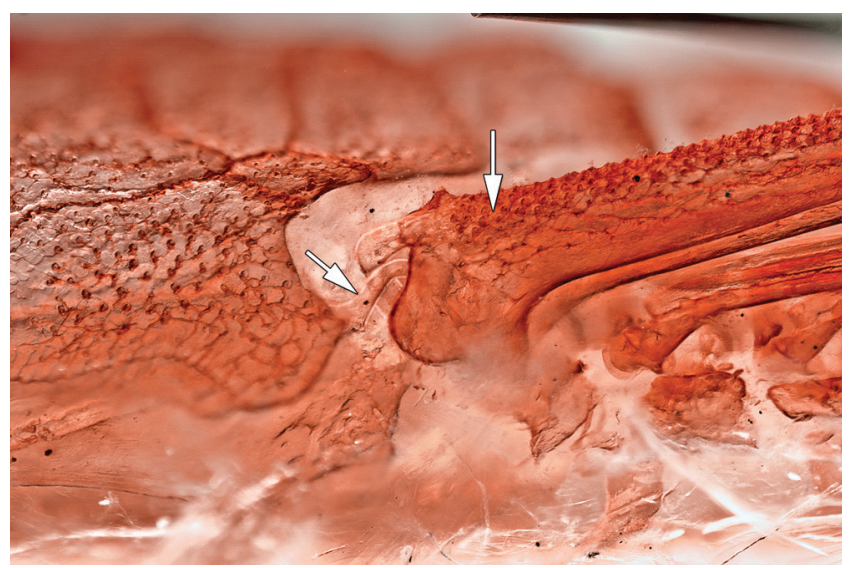

Fig. 5. Detail of dorsal view of dorsal-fin spine of Harttia absaberi. Left arrow points to loops of second dorsal-fin pterygiophore, right arrow points to dorsal-fin spine. MZUSP 85806, paratype, $63.9 \mathrm{~mm} \mathrm{SL}$, c\&s.

222.5 mm SL. Pterosturisoma microps: Peru, Iquitos, rio Amazonas, MZUSP 85801, 2, 148.3-168.7 mm SL, Brazil, Amazonas State, rio Solimões, MZUSP 75366, 1, 158.9mm SL. Sturisoma rostratum: Brazil, Mato Grosso State, rio Araguaia, MZUSP 58540, 6, 135.2-212.0 mm SL. Sturisomatichthys leightoni: Colombia, Cauca, Magdalena drainage, río Cauca, CAS 77228, 4, 51.6-103.9 mm SL.

\section{Acknowledgments}

The authors are grateful to Eduardo Baena for preparing the pictures and photos, Oscar Shibatta for the loan of specimens under his care. Mónica Rodríguez greatly contributed by kindly reviewing an earlier version of the manuscript. We are also grateful to Leandro M. Sousa, who designed a tutorial to produce maps, available at www. wikipeixes.com.br, which was used to create the map of distribution of Harttia absaberi. Thanks are due to Mark Sabaj Pérez (ANSP), David Catania (CAS), Lúcia Rapp Py-Daniel (INPA), Paulo A. Buckup (MNRJ), Oscar A. Shibatta (MZUEL), Isaac Isbrücker (RMNH.PISC) for the loan of material. This study was partially supported by the South American Characiformes Inventory (FAPESP 2011/502082-7). Collecting trip to rio Sucuriú supported by Fundação de Amparo à Pesquisa do Estado de São Paulo (FAPESP) within the BIOTA/FAPESP Program - The Virtual Institute of Biodiversity Project No. 00/04300-9, entitled "Diversidade de peixes de riachos e cabeceiras da Bacia do rio Ribeira de Iguape no Estado de São Paulo" and All Catfish Species Inventory (NSF DEB-0315963), IF is supported by the Fundação de Amparo à Pesquisa do Estado de São Paulo (FAPESP 2009/53402-3, 2010/51368$0), \mathrm{FL}$ is partially supported by the Conselho Nacional de Desenvolvimento Científico e Tecnológico (CNPq proc. 305946/2011-0). 


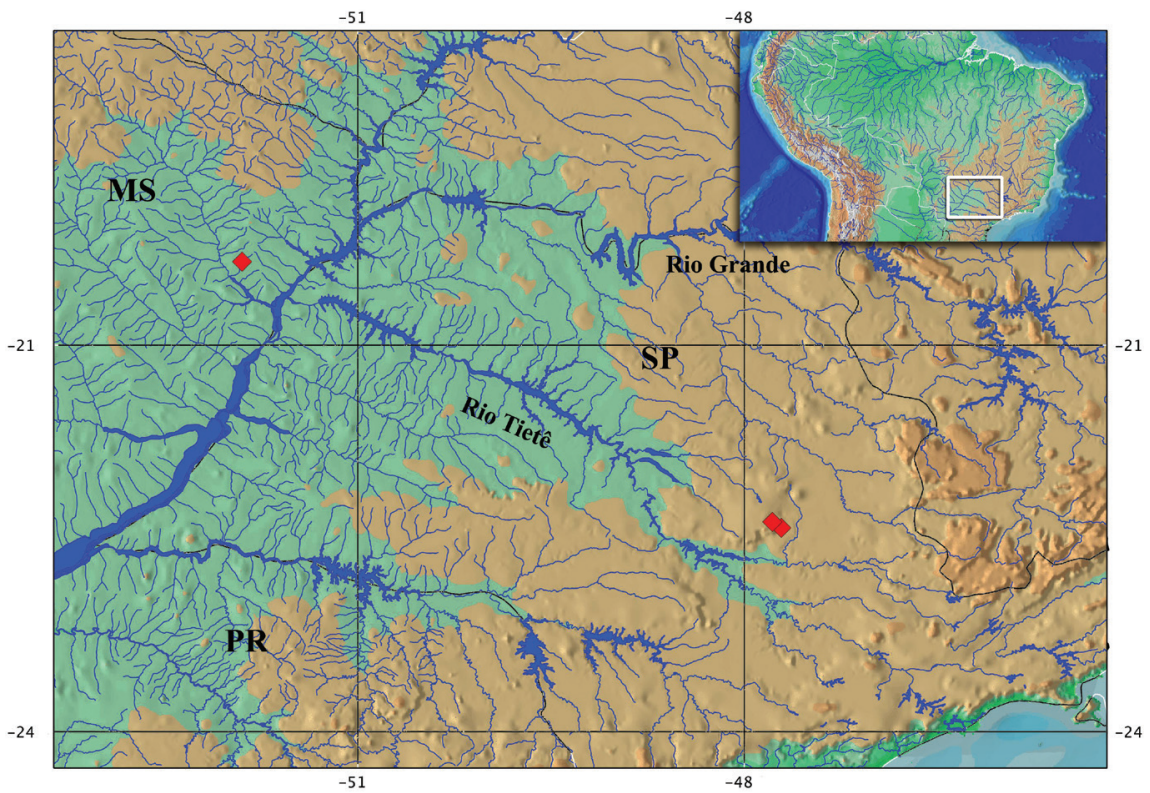

Fig. 6. Map of upper portion of rio Paraná basin showing currently known distribution of Harttia absaberi (red diamond in the left = type locality).

\section{Literature Cited}

Armbruster, J. W. 2004. Phylogenetic relationships of the suckermouth armoured catfishes (Loricariidae) with emphasis on the Hypostominae and the Ancistrinae. Zoological Journal of the Linnean Society, 141: 1-80.

Boeseman, M. 1971. The "combtoothed" Loricariinae of Surinam, with reflections on the phylogenetic tendencies within the family Loricariidae (Siluriformes, Siluroidei). Zoologische Verhandelingen, 116: 1-56.

Covain, R. \& S. Fisch-Muller. 2007. The genera of the Neotropical armored catfish subfamily Loricariinae (Siluriformes: Loricariidae): a practical key and synopsis. Zootaxa, 1642: 1-40.

Covain, R. \& S. Fisch-Muller, J. I. Montoya-Burgos, J. H. Mol, P. Le Bail \& S. Dray. 2012. The Harttiini (Siluriformes, Loricariidae) from the Guianas: a multi-table approach to assess their diversity, evolution, and distribution. Cybium, 36: 115-161.

Ferraris, C. J., Jr. 2007. Checklist of catfishes, recent and fossil (Osteichthyes: Siluriformes), and catalogue of siluriform primary types. Zootaxa, 1418: 1-628.

Isbrücker, I. J. H. 1979. Descriptions préliminaires de nouveaux taxa de la famille des Loricariidae, Poisson-Chats cuirassés néotropicaux, avec un catalogue critique de la sous-famille nominale (Pisces, Siluriformes). Revue française d'aquariologie, 5: 86-116.

Langeani, F., O. T. Oyakawa \& J. I. Montoya-Burgos, 2001. A new species of Harttia (Loricariidae, Loricariinae) from the Rio São Francisco Basin. Copeia, 2001: 136-142.

Langeani, F., R. M. C. Castro, O. T. Oyakawa, O. A. Shibatta, C. S. Pavanelli \& L. Casatti. 2007. Diversidade da ictiofauna do Alto Rio Paraná, composição atual e perspectivas futuras. Biota Neotropica, 7: 181-197.

Montoya-Burgos, J. I., S. Fisch-Muller, C. Weber \& J. Pawlowski. 1998. Phylogenetic relationships of the Loricariidae (Siluriformes) based on mitochondrial rRNA gene sequences. Pp. 363-374. In: Malabarba, L. R., R. E. Reis, R. P. Vari, Z. M. S. Lucena \& C. A. S. Lucena (Eds.). Phylogeny and Classification of Neotropical Fishes. Porto Alegre, Edipucrs.
Paixão, A. C. \& M. Toledo-Piza. 2009. Systematics of Lamontichthys Miranda-Ribeiro (Siluriformes: Loricariidae), with the description of two new species. Neotropical Ichthyology, 7: 519-568.

Rapp Py-Daniel, L. H. 1997. Phylogeny of the Neotropical armored catfishes of the subfamily Loricariinae (Siluriformes:Loricariinae). Unpublished Ph.D. Dissertation, University of Arizona, Arizona, 280p.

Reis, R. E., E. H. L. Pereira \& J. W. Armbuster. 2006. Delturinae, a new loricariid catfish subfamily (Teleostei, Siluriformes), with revisions of Delturus and Hemipsilichthys. Zoological Journal of the Linnean Society, 147: 277-299.

Rodriguez, M. S., H. Ortega \& R. Covain. 2011. Intergeneric phylogenetic relationships in catfishes of the Loricariinae (Siluriformes: Loricariidae), with the description of Fonchiiloricaria nanodon: a new genus and species from Peru. Journal of Fish Biology, (79): 875-895.

Schaefer, S. A. 1987. Osteology of Hypostomus plecostomus (Linnaeus), with a phylogenetic analysis of the loricariid subfamilies (Pisces: Siluroidei). Contributions in Science, 394: 1-31.

Schaefer, S. A. 1997. The neotropical cascudinhos: systematics and biogeography of the Otocinclus catfishes (Siluriformes: Loricariidae). Proceedings of Academy of Natural Sciences of Philadelphia, 148: 1-120.

Vera-Alcaraz, H. S., C. S. Pavanelli \& C. H. Zawadzki. 2012. Taxonomic revision of the Rineloricaria species (Siluriformes: Loricariidae) from the Paraguay River basin. Neotropical Ichthyology, 10: 285-311.

Taylor, W. R. \& G. C. Van Dyke. 1985. Revised procedures for staining and clearing small fishes and other vertebrates for bone and cartilage study. Cybium, 9: 107-119.

Submitted November 14, 2012 Accepted November 8, 2013 by Paulo Lucinda Published December 27, 2013 